\title{
Serum and alveolar procalcitonin had a weak diagnostic value for ventilator-associated pneumonia in patients with pulmonary infection score $\geq 6$
}

\author{
MEHRAN SHOKRI $^{1}$, ROYA GHASEMIAN ${ }^{2}$, MASOMEH BAYANI ${ }^{1}$, PARVIZ AMRI MALEH $^{3}$, \\ MASOUMEH KAMRANI ${ }^{1}$, MAHMOUD SADEGHI-HADDAD-ZAVAREH $^{1}$, SOHEIL EBRAHIMPOUR $^{1}$ \\ ${ }^{1}$ Infectious Diseases and Tropical Medicine Research Center, Health Research Institute, Babol University of Medical Sciences, Babol, I.R. Iran \\ ${ }^{2}$ Antimicrobial Resistance Research Center, Mazandaran University of Medical Sciences, Sari, I.R. Iran \\ ${ }^{3}$ Department of Anesthesiology, School of Medicine, Babol University of Medical Sciences, Babol, I.R. Iran
}

\begin{abstract}
Background. Measuring the serum and alveolar procalcitonin level as inflammatory marker in the diagnosis of ventilator-associated pneumonia (VAP) has been taken into account. In this study, serum and alveolar procalcitonin levels in patients with suspected VAP and patients with confirmed VAP were compared.

Methods. This cross-sectional study was conducted using 50 intubated intensive care unit (ICU) patients, connected to ventilator, from October 2014 to April 2015. 50 patients with clinical pulmonary infection score $\geq 6$ were divided into two groups. Patients whose bronchoalveolar lavage (BAL) has shown the growth of more than $10^{4} \mathrm{CFU} / \mathrm{mL}$ were included in confirmed VAP group and other patients were included in suspected VAP group. Serum and alveolar procalcitonin levels were measured and compared between both groups.

Results. Mean age of patients was $69.10 \pm 42.13$ with a range of $16-90$ years, out of which 23 patients were male (46\%) and 27 patients were female (54\%). Moreover, patients' mean clinical pulmonary infection score was reported to be $7.02 \pm 1.07$. There was a significant relationship between serum and alveolar procalcitonin in suspected patients and patients with an approved form of pneumonia ( $\mathrm{p}=0.001$ and 0.027 ). Area under the curve for alveolar procalcitonin was 0.683 ( sensitivity $=57 \%$; specificity $=80 \%$ ) and for serum procalcitonin 0.751 (sensitivity $=71 \%$; specificity $=73 \%$ ) for the diagnosis of VAP.

Conclusion. According to the results of the present study, we can diagnose ventilatorassociated pneumonia earlier and more accurately by measuring procalcitonin level (particularly alveolar type) in intensive care unit patients.
\end{abstract}

Key words: alveolar procalcitonin; serum procalcitonin; ventilator-associated pneumonia; bronchoalveolar lavage; intensive care unit.

\section{INTRODUCTION}

Ventilator-associated pneumonia (VAP) is one of the most common causes of death from infectious diseases in ICU [1]. The prevalence of this infection varies from 10 to $20 \%$, depending on definition of pneumonia, type of ICU, target population and level of exposure to antibiotics such that $70 \%$ of patients with acute respiratory distress syndrome will suffer from pneumonia during their stay in ICU $[2,3]$. Iran is one of the countries with highest incidence of nosocomial pneumonia in ICU patients with mechanical ventilation [4]. In some reports, the mortality was two times more than in patients without VAP and its crude mortality rate was found to be more than 50\% [5]. This disease is associated with prolonged mechanical ventilation and hospitalization, excessive use of human resources, high treatment costs and high mortality rate.
Procalcitonin is a peptide precursor of calcitonin made of 116 amino acids, which is produced in several body organs in response to inflammation or infection [6]. Its value increases 3 to 6 hours after the initial stimulation and its higher value is associated with worse prognosis [7]. This polypeptide is considered as the primary marker for the diagnosis of infections. Increase in its value can prove the existence of infection, particularly bacterial infection associated with systemic response of the body. Moreover, procalcitonin has been measured and evaluated as predictive factor of infection in various diseases such as cirrhosis of liver and pneumonia $[8,9]$. In recent years, special attention has been paid to the role of increased serum procalcitonin level in lung injury and its infections. Alveolar procalcitonin has also been evaluated in patients with VAP lately and its value in patients with confirmed VAP was microbiologically different 
from patients with suspected VAP [10]. In addition, serum procalcitonin level has been considered as a mortality index. Despite the high incidence of VAP, its diagnosis presents a challenge to physicians because there are many similar conditions in ICU patients such as acute respiratory distress syndrome, sepsis, heart failure and pulmonary atelectasis that reveal similar symptoms. Unfortunately, there is no reliable gold standard for diagnosis of VAP [11]. However, evaluation of serum and alveolar procalcitonin is used in some cases to diagnose VAP. Due to specificity of alveolar procalcitonin for early diagnosis of ventilator-associated pneumonia, this study was also dedicated to usability and comparison of serum and alveolar procalcitonin level in patients with suspected VAP and patients with confirmed VAP.

\section{MATERIALS AND METHODS}

\section{STUDY SUBJECTS}

In this cross-sectional study, the target population included 120 intubated ICU patients (48 hours after intubation) in Ayatollah Rohani Hospital in Babol, Northern Iran, from October 2014 to April 2015 using census method. The exclusion criteria were hypoxia, coagulation disorders, pleural and pulmonary adhesions, empyema and skin infection in insertion site of the tube. Diagnosis of ventilator-associated pneumonia was done according to clinical examination and BAL cultures.

All patients with suspected VAP were examined daily and bronchoalveolar lavage was performed for 50 patients with clinical pulmonary infection score $\geq 6$ and quantitative culture and serum and alveolar procalcitonin evaluation was done using (CPIS) Clinical Pulmonary Infection Score [12]. Alveolar procalcitonin was measured using enzymelinked fluorescence assay (ProCa-S test PCT, Brahms Diagnostics, Norcross, Georgia, USA) and serum procalcitonin was measured using enzymelinked fluorescence assay (VIDAS ${ }^{\circledR}$ BRAHMS PCT assay; Biomerieux, Lyon, France) according to the manufacturer's instructions while considering the limitation of this assay $(0.05 \mathrm{ng} / \mathrm{mL})$. Patients were divided into two groups; patients whose bronchoalveolar lavage (BAL) has shown the growth of more than $10^{4} \mathrm{CFU} / \mathrm{mL}$ were included in confirmed VAP group and other patients were included in suspected VAP group.
The necessary patient information including age, gender, and length of stay in ICU, cause of hospitalization, duration of mechanical ventilation and time of VAP diagnosis were gathered. Serum and alveolar procalcitonin levels were measured and compared between both groups.

\section{STATISTICAL ANALYSIS}

The gathered data were analyzed using SPSS V.22 software. T-test and Chi-Square statistical methods were used for qualitative and quantitative variables. Moreover, receiver operating characteristic (ROC) curve analysis was used for optimal cutoff value. $\mathrm{P}<0.05$ was considered significant.

\section{ETHICAL CONSIDERATION}

The study protocol was approved by the ethics committee of Babol University of Medical Sciences.

\section{RESULTS}

Of 50 studied patients, 23 were male $(46 \%)$ and 27 were female (54\%) with mean age of $69.10 \pm$ 42.13 and a range of 16-90 years. There were 26 patients $(52 \%)$ with suspected VAP and 24 patients $(48 \%)$ with confirmed VAP (Table 1). The mean length of stay in the intensive care unit was $9.74 \pm 2.64$ days. Moreover, patients' mean clinical pulmonary infection score was reported to be $7.02 \pm 1.07$.

Cutoff value for alveolar procalcitonin for the diagnosis of VAP (AUC $=0.683$ ) was calculated to be $709.5 \mathrm{ng} / \mathrm{mL}$ (sensitivity $=57 \%$; specificity $=80 \%$ ) (Figure 1) (Table 3). Accordingly, the mean alveolar procalcitonin with a range of $271-957 \mathrm{ng} / \mathrm{mL}$ was calculated to be $607.80 \pm 199.38 \mathrm{ng} / \mathrm{mL}$. There was a significant difference between alveolar procalcitonin level in patients with suspected VAP and patients with confirmed VAP ( $p=0.027)$ in a way that the mean alveolar procalcitonin was $551.00 \pm$ $200.55 \mathrm{ng} / \mathrm{mL}$ in patients with suspected VAP and was $660.23 \pm 186.97 \mathrm{ng} / \mathrm{mL}$ in patients with confirmed VAP (Table 2). Cutoff value for serum procalcitonin for the diagnosis of VAP $(\mathrm{AUC}=$ 0.751 ) was calculated to be $0.45 \mathrm{ng} / \mathrm{mL}$ (sensitivity = $71 \%$; specificity $=73 \%)($ Figure 1$)($ Table 3$)$. Accordingly, the mean serum procalcitonin level was $046 \pm 0.06 \mathrm{ng} / \mathrm{mL}$ in patients with confirmed 
VAP and it was $0.38 \pm 0.08 \mathrm{ng} / \mathrm{mL}$ in patients with suspected VAP and this difference was significant $(p=0.001)($ Table 2$)$.

Moreover, regarding categorization of clinical pulmonary infection score, patients with CPIS $<8$ had a mean alveolar procalcitonin of $575.45 \pm$ $184.79 \mathrm{ng} / \mathrm{mL}$ and patients with CPIS $\geq 8$ had a mean alveolar procalcitonin of $652.48 \pm 214.42 \mathrm{ng} / \mathrm{mL}$ and the difference was not statistically significant $(\mathrm{p}=0.15)$. In addition, patients with CPIS $<8 \mathrm{had}$ a mean serum procalcitonin of $0.40 \pm 0.08 \mathrm{ng} / \mathrm{mL}$ and patients with CPIS $\geq 8$ had a mean serum procalcitonin of $0.44 \pm 0.07 \mathrm{ng} / \mathrm{mL}$ and no significant difference was reported $(\mathrm{p}=0.07)$.

Lung and heart diseases were respectively the most and the least common causes of hospitalization in ICU patients. Serum and alveolar procalcitonin level in patients with different causes of hospitallization is presented in Table 4. No significant difference was observed between serum and alveolar procalcitonin level and causes of hospitalization in the ICU ( $\mathrm{p}=0.77$ and 0.17 , respectively).

Table 1

Descriptive data for patients with confirmed VAP and patients with suspected VAP

\begin{tabular}{|c|c|c|c|}
\hline \multicolumn{2}{|c|}{ Descriptive data } & Suspected VAP (N = 26) & Confirmed VAP (N = 24) \\
\hline \multirow{2}{*}{ Gender } & Male & $14(53.8 \%)$ & $9(37.5 \%)$ \\
\cline { 2 - 4 } & Female & $12(46.2 \%)$ & $15(62.5 \%)$ \\
\hline \multicolumn{2}{|c|}{ Age } & $69.85 \pm 13.96$ & $68.29 \pm 13.06$ \\
\hline \multicolumn{2}{|c|}{ Length of stay (days) } & $9.54 \pm 2.64$ & $9.96 \pm 2.67$ \\
\hline
\end{tabular}

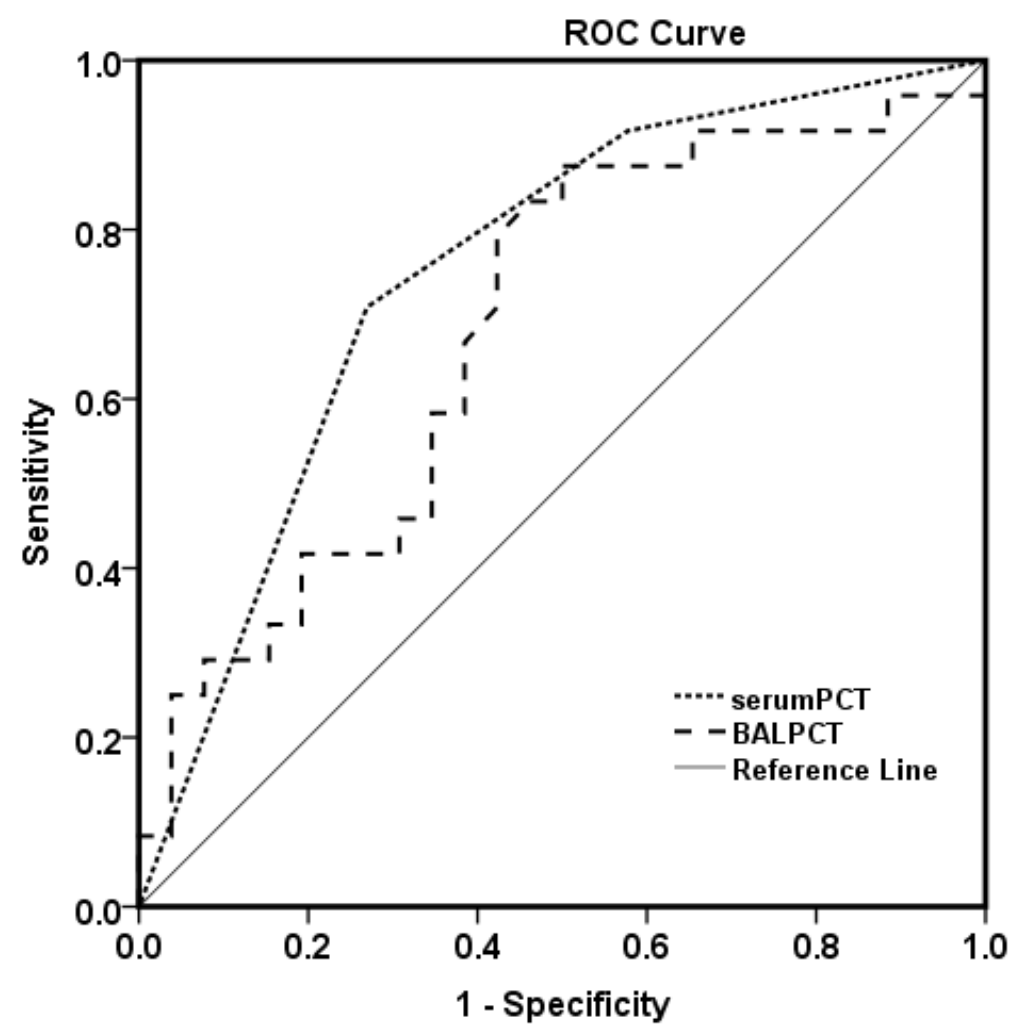

Figure 1. ROC curve: serum and alveolar procalcitonin concentration and the diagnosis of VAP.

Table 2

Alveolar and serum PCT concentration in two groups

\begin{tabular}{|c|c|c|c|}
\hline & $\begin{array}{c}\text { Suspected VAP }(\mathbf{N}=\mathbf{2 6}) \\
(\mathbf{n g} / \mathbf{m L})\end{array}$ & $\begin{array}{c}\text { Confirmed VAP }(\mathbf{N}=\mathbf{2 4}) \\
(\mathbf{n g} / \mathbf{m L})\end{array}$ & Value \\
\hline Alveolar PCT $(\mathbf{S D})$ & $551.00 \pm 200.55$ & $660.23 \pm 186.97$ & 0.027 \\
\hline Serum PCT $($ SD) & $0.38 \pm 0.08$ & $0.46 \pm 0.06$ & 0.001 \\
\hline
\end{tabular}

PCT, Procalcitonin. VAP, Ventilator Associated Pneumonia 
Table 3

Area under the ROC curve; related to serum and alveolar procalcitonin

\begin{tabular}{|c|c|c|c|c|c|}
\hline \multicolumn{5}{|c|}{ Area Under the Curve } \\
\hline $\begin{array}{c}\text { Test Result } \\
\text { Variable(s) }\end{array}$ & Area & Std. Error & Asymptotic Sig & \multicolumn{2}{|c|}{$\begin{array}{c}\text { Asymptotic 95\% Confidence } \\
\text { Interval }\end{array}$} \\
\cline { 4 - 6 } & & & & Lower Bound & Upper Bound \\
\hline Serum PCT & 0.751 & 0.070 & 0.001 & 0.613 & 0.888 \\
\hline BALPCT & 0.683 & 0.077 & 0.027 & 0.532 & 0.833 \\
\hline
\end{tabular}

Table 4

Mean value and standard deviation of serum and alveolar procalcitonin level in patients with different causes of hospitalization

\begin{tabular}{|c|c|c|}
\hline $\begin{array}{c}\text { Cause of } \\
\text { hospitalization }\end{array}$ & $\begin{array}{c}\text { Serum procalcitonin level } \\
(\mathbf{n g} / \mathbf{m L})\end{array}$ & $\begin{array}{c}\text { Alveolar procalcitonin level } \\
(\mathbf{n g} / \mathbf{m L})\end{array}$ \\
\hline & mean $\pm \mathrm{SD}$ & mean $\pm \mathrm{SD}$ \\
\hline Pulmonary & $0.40 \pm 0.08$ & $623.60 \pm 183.13$ \\
\hline Cerebral & $0.43 \pm 0.08$ & $668.77 \pm 226.84$ \\
\hline Sepsis & $0.41 \pm 0.08$ & $622.17 \pm 210.53$ \\
\hline Heart & $0.42 \pm 0.08$ & $487.60 \pm 139.20$ \\
\hline
\end{tabular}

\section{DISCUSSION}

The present study demonstrated that serum and alveolar procalcitonin level in patients with confirmed VAP was more than patients with suspected VAP. However, there was no significant difference between serum and alveolar procalcitonin level and categorization of clinical pulmonary infection score. Moreover, there was no significant difference between serum and alveolar procalcitonin level and hospitalization in the ICU.

There are similar studies that show there is a significant relationship between serum procalcitonin level and infection and this relationship introduces PCT as a useful test for early detection of systemic infections [13-15]. As a result, major changes in serum procalcitonin concentration make it a useful marker for diagnosis and prognosis of bacterial infections. The study of Aalto et al. regarding serum procalcitonin level showed an increased serum procalcitonin level in patients with infection [16]. Jiao et al., showed that serum PCT may be used as diagnostic marker for VAP in patients following cardiac surgery [17]. Assicot et al. demonstrated the diagnostic value of alveolar procalcitonin regarding the intensity and course of inflammatory responses to bacterial and fungal infections for the first time [18]. Thereafter, several studies have shown the close association of serum and alveolar procalcitonin level and severe invasive bacterial infections and its decline after appropriate antibiotic treatment.

As stated earlier, mean serum and alveolar procalcitonin level in patients with confirmed VAP was more than in patients with suspected VAP.
Therefore, the results of the present study indicate that alveolar procalcitonin can also play a key role for the diagnosis of VAP. Zhou et al. found that alveolar procalcitonin level has high sensitivity in regard with the diagnosis of VAP and we can use the changes in alveolar procalcitonin level for quick diagnosis of VAP in early stages [19]. Liao et al. have reported that measuring alveolar procalcitonin level is highly effective in early diagnosis of VAP [20]. Decline in alveolar procalcitonin level can be predictive of survival due to appropriate response to treatment.

In the study of Duflo et al. serum procalcitonin level in patients with confirmed VAP was significantly higher than in other patients. Although this study demonstrated that accumulation of serum procalcitonin can be useful for the diagnosis of VAP, alveolar procalcitonin level is not useful for the diagnosis of this type of pneumonia and is not a proper marker for predicting mortality [21]. Ramirez et al. found that serum procalcitonin level can be effective in differentiating non-infectious lung diseases from infectious ones and contribute to the diagnosis of VAP; however, no such positive result was found regarding alveolar procalcitonin [22]. Linssen et al. reported in their study that the diagnostic value of alveolar procalcitonin in the diagnosis of VAP is less than serum procalcitonin [23]. In addition, several studies have noted that alveolar procalcitonin is not an exclusive marker for the diagnosis of VAP, whereas serum procalcitonin benefits from this characteristic. Usefulness of alveolar procalcitonin in some studies and its uselessness in some other studies may be due to blind and random 
sampling of bronchoalveolar lavage from uninvolved parts of lung, which may not show a true level of alveolar procalcitonin. The theory stated in the study of Monton et al. may be another reason. In his research, Monton stated that the produced cytokine may not be divided into smaller components and thus accumulation of alveolar procalcitonin may not be observed, which is true in pulmonary infections [24].

Cutoff value for serum procalcitonin was reported to be $0.45 \mathrm{ng} / \mathrm{mL}$ with sensitivity of $71 \%$ and specificity of $73 \%$ and AUC of 0.751 (favorable) and the same index for alveolar procalcitonin was reported to be $709.5 \mathrm{ng} / \mathrm{mL}$ with sensitivity of $57 \%$ and specificity of $80 \%$ and AUC of 0.683 (relatively favorable). Considering the relative equality of test properties, AUC and difference in their sensitivity, one may conclude that, although serum procalcitonin test can be used as a diagnostic method with relatively favorable and cost-effective properties for the diagnosis of VAP, measuring alveolar procalcitonin can also be considered as another useful method for early diagnosis of this infection due to specificity of samples (lung) as opposed to serum procalcitonin which may also increase in other organs.
Therefore, procalcitonin test is advised to be used for patients, whose diagnosis of bacterial infections, particularly VAP, is not certain and serum procalcitonin level should be measured at early stages of the disease and during treatment using this test. There were some limitations in this recent study. The number of subjects was small and hence a study on a larger number of individuals is required. Moreover, cellular and molecular investigations like evaluation of regulatory T-cells as a marker in some infections and gene expression of cytokines related to create infection (VAP) for future study is suggested [25].

\section{CONCLUSION}

Our results can be suggested that measuring the procalcitonin level, particularly alveolar procalcitonin, in ICU patients can contribute to early diagnosis of ventilator-associated pneumonia.

Acknowledgments. The authors acknowledge all staff of the Department of Infectious Diseases, Babol Medical University, Iran.

Conflict of interest. The authors declare that they have no conflict of interests.

Introducere. Măsurarea procalcitoninei serice şi alvelolare ca marker inflamator pentru diagnosticul pneumoniei de ventilator (VAP) a fost luată în considerare. In acest studiu au fost studiate nivelurile procalcitoninei la pacienţii la care se supiciona VAP şi la cei cu VAP confirmată.

Metode. A fost realizat un studiu transversal pe 50 de pacienţi intubaţi. Studiul s-a desfăşurat din octombrie 2014 până în aprilie 2015. Cei 50 de pacienţi cu scor clinic de infecţie $\geq 6$ au fost împărţiţi în două grupuri. Cei care au avut din lavajul bronhoalveolar (BAL) mai mult de $10^{4} \mathrm{CFU} / \mathrm{mL}$ au fost incadraţi la pacienţi cu VAP confimată pe când ceilalți au fost incluşi în grupul cu VAP suspectată. Nivelurile serice şi din BAL ale procalcitoninei au fost analizate în ambele grupuri.

Rezultate. Vârsta medie a fost de $69.10 \pm 42.13$ (între 16 şi 90 ani). 23 au fost bărbaţi şi 27 au fost femei. Scorul mediu de infecţie pulmonară a fost $7.02 \pm$ 1.07. Nivelurile procalcitoninei serice şi alvelolare s-au corelat la pacienţii cu VAP confimată cât şi la cei cu VAP suspectă. Aria de sub curba ROC pentru diagnosticul VAP pentru procalcitonina alveolară a fost de 0.683 (sensibilitate $57 \%$ şi specificitate $80 \%$ ) şi pentru procalcitonina serică a fost de 0.751 (sensibilitate $71 \%$, specificitate $73 \%$ ).

Concluzii. Conform acestui studiu putem diagnostica VAP mai devreme folosind nivelurile procalcitoninei (mai ales cea alveolară) la pacienţii internaţi în secţiile de terapie intensivă.

Correspondence to: Soheil Ebrahimpour, $\mathrm{PhD}$,

Infectious Diseases and Tropical Medicine Research Center, Health Research Institute, Babol University of Medical Sciences, Babol, I.R. Iran

Tel: +989111149309; Fax: +981132207918

E-mail: drsoheil1503@yahoo.com 


\section{REFERENCES}

1. LIU D., LIAN H., WANG J., LI X., ZHAO Q., YOU Q. Efficacy of early bundle therapy on moderate to severe aspiration pneumonia after cervical esophagogastrostomy for esophageal cancer. Minerva Medica 2015; 106(2):79-86.

2. MATHI AS., PHILLIPS A., ISAAC R. Ventilator-associated pneumonia: A persistent healthcare problem in Indian Intensive Care Units! Lung India 2016; 33(5):512-6.

3. CLAVEL M., BARRAUD O., MOUCADEL V., MEYNER F., KARAM E., PLOY M.C. et al. Molecular quantification of bacteria from respiratory samples in patients with suspected ventilator-associated pneumonia. Clin Microbiol Infect 2016; 22(9):812.e1-.e7.

4. AMRI MALEH P., BAYANI M., NIKBAKHSH N., POURHASSAN A., MARZBAN M., SHIRKHANI Z., et al. Incidence, causes and outcomes of ventilator-associated pneumonia in the medical intensive care unit. J Urmia Nurs Midwif 2013; 11(7).

5. IOANAS M., FERRER R., ANGRILL J., FERRER M., TORRESA. Microbial investigation in ventilator-associated pneumonia. Eur Respir 2001;17(4):791-801.

6. SHIFERAW B., BEKELE E, KUMAR K., BOUTIN A., FRIERI M. The role of procalcitonin as a biomarker in sepsis. J Infect Dis Epidemiol 2016; 2(006).

7. DAVIES J. Procalcitonin. J Clin Pathol 2015; 68(9):675-9.

8. VILLAREAL E., VACACELA K., GORDON M., CALABUING C., ALONSO R., RUIZ J., et al. Usefulness of procalcitonin for diagnosing infection in critically ill patients with liver cirrhosis. Med Intensiva (English Edition) 2016; 40(2):84-9.

9. GILBERT D., GELFER G., WANG L., MYERS J., BAJEMA K., JOHNSTON M., et al. The potential of molecular diagnostics and serum procalcitonin levels to change the antibiotic management of community-acquired pneumonia. Diagn Microbiol Infect Dis 2016; 86(1):102-7.

10. DALLAS J., BROWN SM., HOCK K., SCOTT MG., SKRUPKY LP., BOYLE WA., et al. Diagnostic utility of plasma procalcitonin for nosocomial pneumonia in the intensive care unit setting. Respir care 2011; 56(4):412-9.

11. LISBOA T., RELLO J. Diagnosis of ventilator-associated pneumonia: is there a gold standard and a simple approach? Cur opin infect dis 2008; 21(2):174-8.

12. PIERACCI FM., RODIL M., HAENEL J., STOVALL RT., JOHNSON JL., BURLEW CC., et al. Screening for VentilatorAssociated pneumonia in the surgical intensive care unit: A single-institution analysis of 1,013 lower respiratory tract cultures. Surg infect 2015; 16(4):368-74.

13. ENGEL H., HAMOUDA NB., PORTMANN K., DELODDER F., SUYS T., FEIHL F., et al. Serum procalcitonin as a marker of post-cardiac arrest syndrome and long-term neurological recovery, but not of early-onset infections, in comatose post-anoxic patients treated with therapeutic hypothermia. Resuscitation 2013; 84(6):776-81.

14. LIN K-H., WANGF-L., WUM-S., JIANG B-Y., KAO W-L., CHAO H-Y., et al. Serum procalcitonin and C-reactive protein levels as markers of bacterial infection in patients with liver cirrhosis: a systematic review and meta-analysis. Diagn Microbiol Infect Dis 2014; 80(1):72-8.

15. SERIO I., ARNAUD L., MATHIAN A., HAUSFATER P., AMOURA Z. Can procalcitonin be used to distinguish between disease flare and infection in patients with systemic lupus erythematosus: a systematic literature review. Clin rheumatol 2014; 33(9):1209-15.

16. AALTO H., TAKAKLA A., KAUTIAINEN H., REPO H. Laboratory markers of systemic inflammation as predictors of bloodstream infection in acutely ill patients admitted to hospital in medical emergency. Eur J Clin Microbiol Infect Dis 2004; 23(9):699-704.

17. JIAO J., WANG M., ZHANG J., SHEN K., LIAO X., ZHOU X. Procalcitonin as a diagnostic marker of ventilator-associated pneumonia in cardiac surgery patients. Exp Ther Med 2015; 9(3):1051-57.

18. ASSICOT M., BOHUON C., GENDREL D., RAYMOND J., CARSIN H., GUILBAUD J. High serum procalcitonin concentrations in patients with sepsis and infection. The Lancet 1993; 341(8844):515-8.

19. ZHOU C., LU Z., REN N., ZHANG G. [Diagnostic value of procalcitonin in ventilator associated pneumonia]. Zhongguo wei zhong bing ji jiu yi xue 2006; 18(6):370-2.

20. LIAO X., JIN X., KANG Y., DENG Y., ZHANG Z., ZHOU Y., et al. Role of procalcitonin in the diagnosis of ventilatorassociated pneumonia. Zhongguo wei zhong bing ji jiu yi xue 2010; 22(3):142-5.

21. DUFlO F., DEBON R., MONNERET G., BIENVENU J., CHASSARD D., ALLAOUCHICHE B. Alveolar and serum procalcitonin diagnostic and prognostic value in ventilator-associated pneumonia. Anesthesiol 2002; 96(1):74-9.

22. RAMIREZ P., GARCIA M., FERRER M., AZNAR J., VALENCIA M., SAHUQUILLO J., et al. Sequential measurements of procalcitonin levels in diagnosing ventilator-associated pneumonia. EurRespir J 2008; 31(2):356-62.

23. LINSSEN CF., BAKERS O., DRENT M., JACOBS JA. C-reactive protein and procalcitonin concentrations in bronchoalveolar lavage fluid as a predictor of ventilator-associated pneumonia. Ann clin biochem 2008; 45(3):293-8.

24. MONTON C., TORRES A., El-EBIARY M., FILELLA X., XAUBET A., DELA BELLACASA JP. Cytokine expression in severe pneumonia: a bronchoalveolar lavage study. Crit care med 1999; 27(9):1745-53.

25. HASANJANI ROUSHAN MR., BAYANI M., SOLEIMANI AMIRI S., MOHAMMADNIA-AFROUZI M., NOURI HR., EBRAHIMPOUR S. Evaluation of CD4+CD25+ FoxP3+ regulatory T cells during treatment of patients with brucellosis. J Biol Regul Homeost Agents 2016; 30:675-682.

Received September 10, 2017 